\title{
In vitro micropropagation of a tree legume adapted to arid lands Acacia tortilis subsp raddiana
}

\author{
D Nandwani \\ Department of Botany, ML Sukhadia University, Udaipur-313001, India
}

(Received 25 April 1993; accepted 3 August 1994)

\begin{abstract}
Summary - A procedure is described for micropropagation of Acacia tortilis subsp raddiana (Forsk) Hayne (Mimosoideae) using embryonic explants. Shoot bud formation from cotyledonary nodes was observed on Murashige and Skoog (MS) medium containing various doses of cytokinins (2.5-5.0 $\mathrm{mg} / \mathrm{l})$ viz 6-benzyl adenine (BA) and kinetin, with or without incorporation of auxin $(0.1-0.25 \mathrm{mg} / \mathrm{l}) \mathrm{viz}$ 1-naphthalene acetic acid (NAA) and indole acetic acid (IAA). Multiple shoot regeneration (13-15) was achieved on MS medium supplemented with NAA $(0.1 \mathrm{mg} / \mathrm{l})$ and BA $(5.0 \mathrm{mg} / \mathrm{l})$. Incorporation of auxin, eg, IAA and NAA promoted callusing in the explants. Shoot bud formation was restricted to the cotyledonary node and proximal region of the cotyledons. Scanning electron microscopy showed that shoot bud induction was visible after $5 \mathrm{~d}$ of culture. No regeneration of shoot buds from the hypocotyl explants was observed with any treatment used. Half-strength MS medium containing indole butyric acid $(3.0 \mathrm{mg} / \mathrm{l})$ was found suitable for rooting in regenerated shoots. In vitro developed plantlets were transferred into soil.
\end{abstract}

Acacia tortilis / mimosoideae / forestry / micropropagation / plantlet

Résumé - Micropropagation in vitro d'une Légumineuse de zone aride : Acacia tortilis subsp raddiana. Une méthode a été développée pour la multiplication de pousses et la formation de plants in vitro à partir d'explants d'embryons d'Acacia tortilis (Forsk) Hayne, ssp raddiana (Mimosoïdées). Cette Légumineuse est un arbre important adapté aux conditions arides, élevé en particulier pour la stabilisation des dunes et les programmes de reboisement dans différentes zones arides du monde. Les graines d'A tortilis, récoltées sur des génotypes sélectionnés par le CAZRI, ont été mises à germer in vitro sur un milieu de Murashige et Skoog (MS), sans régulateurs de croissance. Différents types d'explants (hypocotyles, cotylédons, axes embryonnaires [= nœuds cotylédonaires]) ont été excisés à partir de semis d'une semaine. Différents régulateurs de croissance ont été incorporés au milieu MS pour les études de régénération. L'induction de pousses à partir d'explants de nœuds cotylédonaires a été observée dès le $5^{e} j$ de culture, comme en témoignent les obsenvations faites en microscopie électronique à balayage. La régénération de pousses est favorisée par l'addition dans le milieu de concentrations élevées de cytokinines (2,5 à $\left.5 \mathrm{mg} . \mathrm{I}^{-1}\right)$ avec ou sans auxine $\left(0,1\right.$ à $\left.0,25 \mathrm{mg} . \mathrm{r}^{-1}\right)$ (tableau 1$)$. Jusqu'à 13 pousses peuvent se différencier à partir d'explants élevés sur milieu de MS additionné d'ANA $\left(0,1 \mathrm{mg} . \mathrm{t}^{-1}\right)$ et de $B A\left(5 \mathrm{mg} . \mathrm{t}^{-1}\right)$. La croissance et la multiplication des pousses est stimulée par des repi- 
quages à 4 sem d'intervalle. Sur les explants se forment à la fois des pousses axillaires et des pousses adventives. II n'y a en revanche eu aucune régénération à partir d'hypocotyles ou de cotylédons, et cela quels que soient les traitements. Des pousses feuillées, bien allongées, ont été obtenues à partir du milieu de multiplication après 10 à 12 sem de culture. Elles se sont enracinées (tableau II) sur milieu MS à la dilution 1/2 contenant de l'AlB (3 mg..$\left.^{-1}\right)$. L'ANA s'est avéré moins efficace que l'AlB pour l'enracinement. L'adjonction de concentrations d'auxine plus élevées (>3 mg..$\left.^{-1}\right)$ favorise la formation de cals à la base des pousses. Des plantules développées in vitro ont avec succès été élevées pendant 2 mois en conditions non stériles. Le système de régénération ainsi obtenu peut être utile pour la multiplication en masse d'A tortilis.

\section{Acacia tortilis / Mimosoïdées / forêt / micropropagation / plant in vitro}

\section{INTRODUCTION}

Acacia tortilis subsp raddiana (Forsk) Hayne is a medium sized (4-15 $\mathrm{m}$ tall), multipurpose nitrogen-fixing tree and the second most extensively planted taxon after Prosopis species in the Thar desert of northwestern India. It occurs naturally in Africa, the middle East, Sahel, Sudan and India. The plant can withstand arid conditions better than other species of Acacia and Prosopis cineraria (Anon, 1980). It is economically important for fuel, fodder, timber and for sand-dune stabilization and afforestation.

Tissue culture has been used for cloning superior genotypes and in breeding programmes of woody perennials (Karnoski, 1981; Boulay, 1987). Because of the immense importance of nitrogen-fixing trees and shrubs in afforestation and soil erosion control programmes, attempts have been made to regenerate important leguminous tree species through tissue culture, eg, Albizzia falcatoria (Sinha and Mallick, 1993), A richardiana (Tomar and Gupta, 1988), Dalbergia sissoo (Mukhopadhyay and Mohan Ram, 1981), $D$ latifolia (Rai and Chandra, 1989), Tamarindus indica (Jaiwal and Gulati, 1991), $P$ tamarugo (Nandwani and Ramawat, 1992), $P$ cineraria (Nandwani and Ramawat, 1993), and Sesbania sesban (Shankar and Mohan Ram, 1990). Although tissue culture of Acacia has received little attention (Skolmen, 1986), it was in fact one of the first plants grown in culture (Bonner, 1942). A few reports are available on cell suspension cultures or plantlet regeneration from embryonic explants viz $A$ albida (Duhoux and Davies, 1985). A auriculiformis (Mittal et al, 1989), $A$ koa (Skolmen, 1978, 1986), A senegal (Dave et al, 1980), A mangium (Galiana et al, 1991) and $A$ nilotica (Dewan et al, 1992). None of them have described the largescale multiplication of Acacia species.

The present communication reports in vitro shoot multiplication and plantlet regeneration in A tortilis, which is a part of our long-term goal in development of technology for regeneration of forest trees.

\section{MATERIALS AND METHODS}

\section{Plant material}

Seeds of $A$ tortilis subsp raddiana were obtained from the selected genotypes through the silviculture division, Central Arid Zone Research Institute, Jodhpur, India. Seeds were pretreated with $\mathrm{H}_{2} \mathrm{SO}_{4}(30 \%)$ for $15 \mathrm{~min}$ and washed under a runnning tap water for 2-3 $\mathrm{h}$. Seeds were surface disinfected by ethanol $(90 \%)$ for $2 \mathrm{~min}$ followed by mercuric chloride $(0.1 \%)$ for $5 \mathrm{~min}$ and then washed with sterilized distilled water. Finally, seeds were transferred into half-strength Murashige and Skoog (1962) medium (MS) containing $0.6 \%$ agar and $2 \%$ sucrose with no growth regulators. Various explants, eg, hypocotyls, cotyledons, and cotyledonary node (cotyledons + 
axillary meristem) were excised from the 7-10day-old seedlings.

\section{Culture medium}

MS medium was used throughout the investigations. Various growth regulators, eg, 1-naphthalene acetic acid (NAA), indole-3-acetic acid (IAA), 6-benzyl adenine (BA) and kinetin, were used for regeneration studies at a range of concentrations. The $\mathrm{pH}$ of the medium was adjusted to 5.8 with $0.01 \mathrm{~N} \mathrm{KOH}$ or $0.01 \mathrm{~N} \mathrm{HCl}$ before autoclaving at $121^{\circ} \mathrm{C}$ for $20 \mathrm{~min}$.

\section{Culture conditions}

Hypocotyls $(0.5-0.7 \mathrm{~cm})$ and cotyledons $(0.8-1.0$ $\mathrm{cm}$ ) were placed upright and adaxial, respectively, 2 in each culture tube $(125 \times 25 \mathrm{~mm}$, Borosil) or Erlenmayer flask containing 20 and $40 \mathrm{ml}$ culture medium, respectively. Cotyledonary node explants $(1.0-1.2 \mathrm{~cm})$ were cultured singly in culture tubes or in pairs in Erlenmayer flasks. Culture vessels were incubated under fluorescent and incandescent lights with $16 \mathrm{~h}$ illumination (2 500 lux) at $26 \pm 1^{\circ} \mathrm{C}$ temperature and $55 \%$ $( \pm 5 \%)$ relative humidity. Each treatment consisted of 24-30 replicates, and cultures for multiplication and elongation were grown for at least 3 passages of 4 weeks duration using conditions similar to those described above except that cotyledons were removed from the multiple shoot buds prior to subculture in the second passage.

\section{Rooting and transplantation}

Well-elongated leafy shoots $(3.0-4.0 \mathrm{~cm})$ of 8-12 weeks age were transferred into half-strength MS medium supplemented with 3-indole butyric acid (IBA) or NAA at various concentrations (1.0-5.0 mg/l). In vitro-developed plantlets were removed carefully from the culture vessels and adhered agar was removed to avoid contamination. Plantlets were washed with distilled water and transferred to plastic pots containing garden soil and vermiculite $(1: 1, v / v)$. Pots were kept in a plant growth chamber for 2-4 weeks before transferring to the glass-house and finally to the field.

\section{Scanning electron microscopy (SEM)}

Cotyledonary node explants were removed at $5 d$ intervals from the bud induction medium and fixed in formaline acetic acid and dehydrated in a graded acetone/amyl acetate series to absolute amyl acetate. They were then critical-point dried with liquid $\mathrm{CO}_{2}$, mounted and sputter coated with 100-200 A gold film. Explants were viewed at 10 $\mathrm{kV}$ in a Jeol $35 \mathrm{CF}$ SEM and photographed (Rhonda and Dodd, 1990).

\section{RESULTS AND DISCUSSION}

Of all the explants used, cotyledonary node segments were found to be best for the multiple shoot induction. Hypocotyl and cotyledon explants produced only callus and no regeneration of shoot buds was achieved from such explants. Shoot bud formation from cotyledonary node explants was observed on almost all of the treatments with growth regulators incorporated in MS medium, singly or in combination (table I). On MS medium containing NAA $(0.1 \mathrm{mg} / \mathrm{l})$ and BA (5.0 mg/l) 13-15 shoot buds were differentiated from the explants (fig 1). The original cotyledonary node explants with multiple shoot buds were repeatedly transferred to fresh culture media for shoot multiplication and enlongation. Formation of new shoot buds (adventitious) and development of older shoots were observed simultaneously. Well-developed shoots (fig 2) could be harvested after up to 5 passages at an interval of 4 weeks. The same technique has been used for the micropropagation of $P$ tamarugo (Nandwani and Ramawat, 1992), $P$ cineraria (Nandwani and Ramawat, 1993) and A nilotica (Dewan et al, 1992). It was observed that production of shoot buds was not affected by the size of explants used, but if the cotyledons were removed in the first passage of 4 weeks, the number of shoot buds formed was decreased (data not shown) as reported earlier (Nandwani and Ramawat, 1992, 1993). Of the cytokinins 
Table I. The morphogenetic response of cotyledonary node explants of $A$ tortilis to various growth regulators incorporated in the MS medium. a

\begin{tabular}{|c|c|c|c|c|c|}
\hline \multicolumn{2}{|c|}{$\begin{array}{l}\text { Growth regulator } \\
(\mathrm{mg} / \mathrm{l})\end{array}$} & $\begin{array}{c}\text { No of shoot buds/ } \\
\text { explants }( \pm S D)\end{array}$ & $\begin{array}{c}\text { Shoot length }(\mathrm{cm}) \\
( \pm S D)\end{array}$ & $\begin{array}{l}\text { Explants } \\
\text { regenerated (\%) }\end{array}$ & Callusing $\mathrm{b}$ \\
\hline $\begin{array}{r}\text { Control } \\
\text { BAP }\end{array}$ & & - & - & - & - \\
\hline 0.1 & & $0.7 \pm 0.48$ & $1.77 \pm 0.74$ & 20 & - \\
\hline 0.5 & & $1.7 \pm 0.53$ & $1.85 \pm 0.64$ & 35 & - \\
\hline 1.0 & & $1.9 \pm 0.99$ & $2.03 \pm 0.79$ & 40 & - \\
\hline 2.5 & & $4.55 \pm 1.13$ & $4.05 \pm 1.71$ & 65 & + \\
\hline 5.0 & & $8.6 \pm 2.22$ & $2.67 \pm 2.24$ & 80 & + \\
\hline Kinetin & & & & & \\
\hline 0.1 & & $1.0 \pm 0.47$ & $1.15 \pm 0.65$ & 15 & - \\
\hline 0.5 & & $1.6 \pm 0.966$ & $1.33 \pm 0.47$ & 25 & - \\
\hline 1.0 & & $2.8 \pm 0.788$ & $1.67 \pm 0.46$ & 40 & - \\
\hline 2.5 & & $6.5 \pm 2.01$ & $2.2 \pm 0.758$ & 70 & + \\
\hline 5.0 & & $8.2 \pm 1.75$ & $2.94 \pm 1.2$ & 90 & + \\
\hline Kinetin & IAA & & & & \\
\hline 0.5 & 0.25 & $2.7 \pm 0.82$ & $1.65 \pm 0.46$ & 20 & + \\
\hline 2.0 & 0.25 & $4.7 \pm 1.159$ & $2.46 \pm 0.61$ & 30 & + \\
\hline 4.0 & 0.25 & $7.9 \pm 1.37$ & $2.8 \pm 0.76$ & 70 & t+ \\
\hline 5.0 & 0.25 & $9.2 \pm 1.549$ & $3.5 \pm 1.1$ & 65 & ++ \\
\hline BAP & NAA & & & & \\
\hline 0.5 & 0.1 & $1.9 \pm 0.737$ & $1.71 \pm 0.52$ & 15 & t \\
\hline 2.0 & 0.1 & $4.1 \pm 0.87$ & $2.61 \pm 0.598$ & 55 & + \\
\hline 4.0 & 0.1 & $9.5 \pm 1.08$ & $2.98 \pm 0.82$ & 80 & + \\
\hline 5.0 & 0.1 & $11.66 \pm 2.12$ & $3.54 \pm 1.06$ & 95 & ++ \\
\hline
\end{tabular}

a Each experiment was repeated 3 times and data were scored after 4 weeks. b Relative value of callus formation: - zero; +, poor; ++, moderate.

used, BA was found to be better than kinetin for induction and multiplication of shoots. Addition of kinetin instead of BA in the medium resulted in the production of a lower number of shoots. Incorporation of auxin (either IAA or NAA) enhanced shoot induction but promoted callusing in the explants. SEM observations (fig 3) supported the fact that shoot bud induction was started rapidly in $5 \mathrm{~d}$ after inoculation. One large shoot from the apical meristem (main shoot) developed quickly in 4-5 $d$ followed by multiple shoot bud induction (5-6 d) at the cotyledonary nodes. The number of shoot buds was increased (12-13 d) as the explants were grown in successive subcultures.

\section{Rooting of shoots}

Induction of roots in regenerated shoots was observed on MS medium containing IBA or NAA (1.0-5.0 mg/l) (table II). Half-strength MS medium supplemented with IBA 
Table II. Effect of auxin on root formation of in vitro regenerated shoots of $A$ tortilis grown on MS medium (1/2 strength) under low light intensity (1000-1500 lux).

\begin{tabular}{|c|c|c|c|}
\hline $\begin{array}{l}\text { Auxin } \\
(m g / l)\end{array}$ & $\begin{array}{c}\text { Number of roots/ } \\
\text { shoot }( \pm S D)\end{array}$ & $\begin{array}{l}\text { Rooted shoots } \\
\text { (\%) }\end{array}$ & Callusing \\
\hline$--\quad-$ & & & \\
\hline Control & - & - & - \\
\hline \multicolumn{4}{|l|}{ IBA } \\
\hline 1.0 & $3.0 \pm 0.89$ & 25 & - \\
\hline 3.0 & $7.5 \pm 1.048$ & 65 & - \\
\hline 5.0 & $3.66 \pm 1.36$ & 55 & + \\
\hline \multicolumn{4}{|l|}{ NAA } \\
\hline 1.0 & $2.16 \pm 1.16$ & 20 & - \\
\hline 3.0 & $4.0 \pm 1.41$ & 45 & + \\
\hline 5.0 & $4.5 \pm 1.04$ & 40 & ++ \\
\hline
\end{tabular}

(3.0 mg/l) was found suitable for rooting as compared to NAA (fig 4). Five to 7 , thin, white-creamish, roots developed directly at the base of shoots without callus formation. Up to $65 \%$ rooting was achieved in differentiated shoots of $A$ tortilis. Higher concentrations of auxins $(5.0 \mathrm{mg} / \mathrm{l})$ favoured callusing in the shoots. In vitro-developed plantlets were transferred to pots and grown for up to 2 months in non-sterile conditions (fig 5).

Multiple shoot formation and plantlet regeneration from cotyledonary nodes has been achieved in $A$ tortilis. Several species of Acacia have been grown in vitro (Skolmen, 1986) and shoot formation from juvenile tissues has been reported in $A$ albida (Duhoux and Davies, 1985). A auriculiformis (Mittal et al, 1989; Rao and Prasad, 1991), A nilotica (Dewan et al, 1992). In all cases, high concentrations of cytokinin along with low amounts of an auxin, or sometimes without an auxin, produced a few shoots from cotyledonary nodes or hypocotyl explants. In our case, shoot buds were initiated very rapidly after the explant was transferred to culture medium, as supported by SEM stud- ies. However, multiplication and elongation of regenerated shoot buds was slow in $A$ tortilis as compared to $P$ cineraria (Nandwani and Ramawat, 1993). The system developed in $A$ tortilis requires further experimentation to increase the growth rate and multiplication. It is suggested that the technique described can be utilized for afforestation and conservation of germplasm of $A$ tortilis.

\section{ACKNOWLEDGMENT}

The author thanks the head of the RSIC of NE Hill University, Shillong for scanning electron microscopy and KG Ramawat for valuable suggestions. Financial support from CSIR, New Delhi is gratefully acknowledged.

\section{REFERENCES}

Anon (1980) Tropical legumes: Resources for the future. Nat Acad Sci, Washington, DC, USA, 231

Bonner $J$ (1942) Culture of isolated roots of Acacia melanoxylon. Bull Torr Bot Club 69, 130-133 

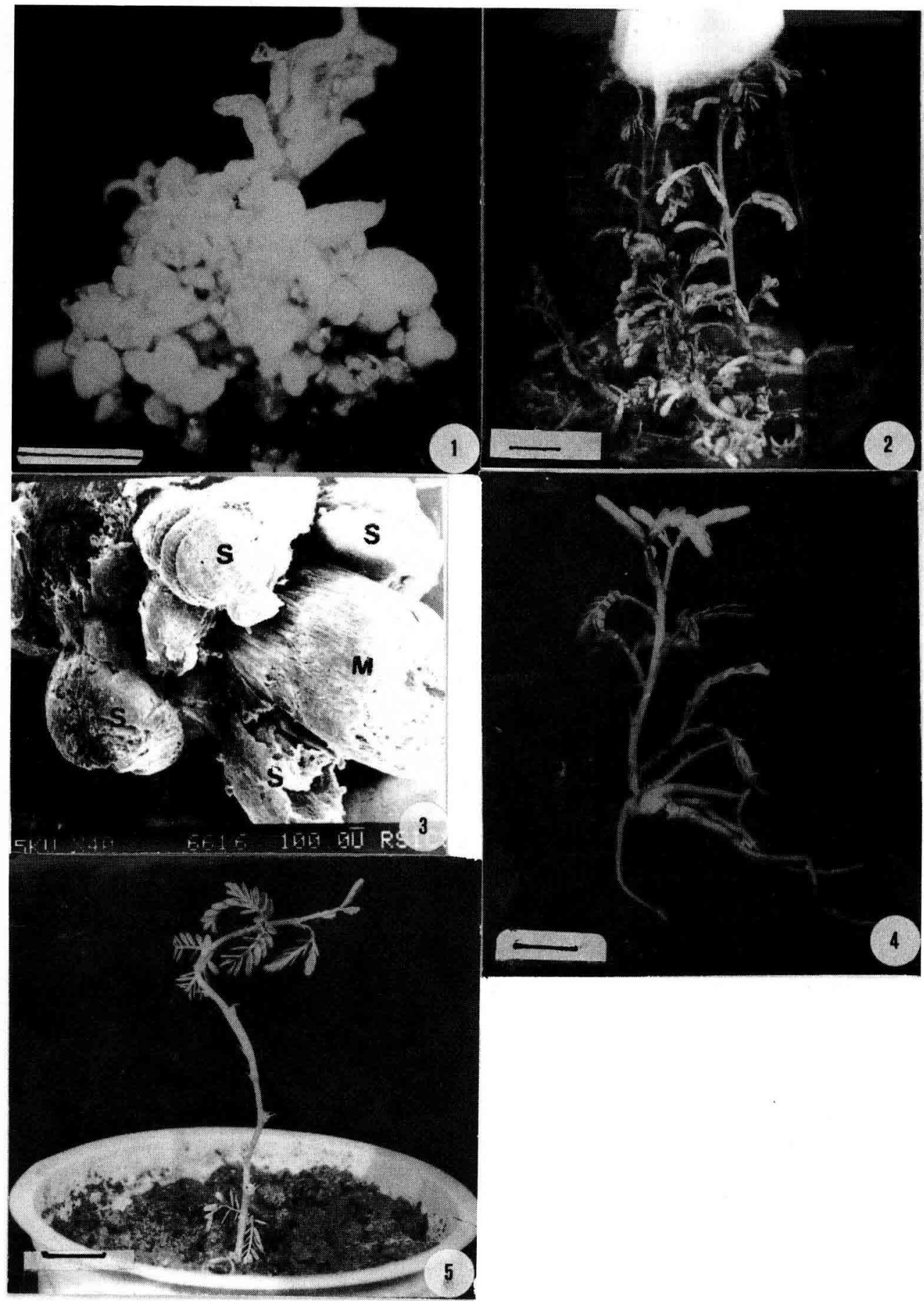
Boulay M (1987) In vitro propagation of tree species. In: Plant Tissue and Cell culture (CE Green, DA Somers, WP Hachett, DD Biespoer, AR Liss, eds) Acad Press Inc, New York, USA, 367-382

Dave VS, Goyal $Y$, Vaishnava GR, Surana NM, Arya HC (1980) Clonal propagation of desert plants through tissue culture. III. Plantlet formation in Acacia senegal stem culture. J Ind Bot Soc 59, 57

Dewan A, Nanda K, Gupta SC (1992) In vitro micropropagation of Acacia nilotica subsp indica Brenan via cotyledonary nodes. Plant Cell Rep 12, 18-21

Duhoux $E$, Davies D (1985) Shoot production from cotyledonary buds of Acacia albida (synonym Faidherbia albida) and influence of sucrose on rhizogenesis. J Plant Physiol 121, 175-180

Galiana A, Tibok A, Duhoux E (1991) In vitro propagation of nitrogen-fixing tree legume Acacia mangium Willd. Plant Soil 135, 151-159

Jaiwal PK, Gulati A (1991) In vitro high frequency plant regeneration of a tree legume Tamarindus indica (L). Plant Cell Rep 10, 569-573

Karnoski DF (1981) Potential for forest tree improvement via tissue culture. Bioscience 31, 114-120

Mittal A, Aggrawal R, Gupta SC (1989) In vitro development of plantlets from axillary buds of Acacia auriculiformis - a leguminous tree. Plant Cell Tissue Organ Cult 19, 65-70

Mukhopadhyay A, Mohan Ram HY (1981) Regeneration of plantlets from excised roots of Dalbergia sissoo. Ind J Exp Biol 19, 1113-1115

Murashige T, Skoog F (1962) A revised medium of rapid growth and bioassays wih tobacco tissue culture. Physiol Plant 15, 473-496
Nandwani D, Ramawat KG (1992) High frequency plantlets regeneration from seedling explants of Prosopis tamarugo. Plant Cell Tissue Organ Cult 29, 173-178

Nandwani D, Ramawat KG (1993) In vitro plantlets formation through juvenile and mature explants in Prosopis cineraria. Ind J Exp Biol 31, 156-160

Rai RV, Chandra KSJ (1989) Micropropagation of Indian rosewood by tissue culture. Ann Bot 64, 43-46

Rao GVR, Prasad MNV (1991) Plantlet regeneration from the hypocotyl callus of Acacia auriculiformis - multipurpose tree legume. J Plant Physiol 137, 625-627

Rhonda LG, Dodd WA (1990) An in vitro technique for the production de novo of multiple shoots in cotyledon explants of cucumber (Cucumis sativus L). Plant Cell Tissue Organ Cult 20, 177-183

Shankar S, Mohan Ram HY (1990) Plantlets regeneration from tissue cultures of Sesbania grandiflora. Curr Sci 59, 39-43

Sinha RK, Mallick R (1993) Regeneration and multiplication of shoot in Albizia falcataria. Plant Cell Tissue Organ Cult 32, 259-261

Skolmen RG (1978) Vegetative propagation of Acacia koa Gray. In: Proc Sec Conf Nat Sci(CW Smith, ed), Hawaii, USA, 260-273

Skolmen RG (1986) Acacia (Acacia koa Gray). In: Biotechnology in Agriculture and Forestry (YPS Bajaj, ed), vol 1, trees I, Springer Verlag, Berlin, Germany, 375-384

Tomar UK, Gupta SC (1988) Somatic embryogenesis and organogenesis in callus cultures of a tree legume Albizia richardiana King. Plant Cell Rep 7, 70-73

Fig 1. Multiple shoot bud formation from the cotyledonary node on MS medium containing NAA $(0.1 \mathrm{mg} / \mathrm{l})$ and $\mathrm{BA}(5.0 \mathrm{mg} / \mathrm{l})$ in the first passage.

Fig 2. Well-developed leafy shoot on MS medium supplemented with BA $(2.0 \mathrm{mg} / \mathrm{l})$ after 8 weeks of culture.

Fig 3. SEM showing induction of shoot buds from the cotyledonary node explants of $A$ tortilis after $5 \mathrm{~d}$ of incubation ( $\mathrm{M}$ - main shoot, $\mathrm{S}$ - shoot buds).

Fig 4. Root formation in regenerated shoots on half-strength MS medium containing IBA $(3.0 \mathrm{mg} / \mathrm{l})$.

Fig 5. Two-month-old in vitro raised plantlet of $A$ tortilis (bar represents $1.0 \mathrm{~cm}$ ). 